\title{
The Heats of Hydrolysis of Aspirin, Thioaspirin, and Their p-Analogues
}

\author{
LISB E T H NELA N D ER
}

Thermochemistry Laboratory, ${ }^{*}$ University of Lund, Sweden

\begin{abstract}
The heats of hydrolysis of $o$-acetylhydroxybenzoic acid (aspirin), $p$-acetylhydroxybenzoic acid, $o$-acetylmercaptobenzoic acid (thioaspirin) and $p$-acetylmercaptobenzoic acid have been determined calorimetrically at $25^{\circ} \mathrm{C}$. For the idealized, isothermal hydrolysis
\end{abstract} reactions

$$
\begin{aligned}
& (o, p) \mathrm{HOCOC}_{6} \mathrm{H}_{4} \mathrm{XAc}(\mathrm{s})+\mathrm{H}_{2} \mathrm{O}(\mathrm{l}) \rightarrow \\
& \rightarrow(o, p) \mathrm{HOCOC}_{6} \mathrm{H}_{4} \mathrm{XH}(\mathrm{s})+\mathrm{HOAc}_{(\mathrm{l})}
\end{aligned}
$$

the enthalpy changes were found to be

$$
\begin{aligned}
& -6.50 \pm 0.07 \mathrm{kcal} / \mathrm{mole} \\
& \text { for } \mathbf{X}=\mathbf{O} \quad(o) \\
& -4.93 \pm 0.08 \quad, \\
& , \mathrm{X}=\mathrm{O} \quad(p) \\
& -5.85 \pm 0.06 \quad, \quad, \quad, \mathrm{X}=\mathrm{S} \quad(o) \\
& -2.75 \pm 0.09 \quad, \quad, \quad, \mathrm{X}=\mathrm{S} \quad(p)
\end{aligned}
$$

By heat of solution measurements, the enthalpy changes for the hypothetical hydrolysis reactions in aqueous solution (ionic strength $=0.1$ )

$$
\begin{aligned}
& (o, p)^{-} \mathrm{OCOC}_{6} \mathrm{H}_{4} \mathrm{XAc}(\mathrm{aq}) \\
& +\mathrm{OAc}^{-}(\mathrm{aq})+\mathrm{H}^{+}(\mathrm{aq})
\end{aligned}+\mathrm{H}_{2} \mathrm{O}(\mathrm{aq}) \rightarrow(o, p)^{-} \mathrm{OCOC}_{6} \mathrm{H}_{4} \mathrm{XH}(\mathrm{aq})+
$$

were found to be

$$
\begin{aligned}
& -4.43 \pm 0.12 \mathrm{kcal} / \mathrm{mole} \\
& -4.95+0.16 \\
& -3.52 \pm 0.15 \quad \text { " } \\
& \text { for } \mathrm{X}=\mathrm{O} \quad(o) \\
& , \mathrm{X}=\mathrm{O} \quad(p)
\end{aligned}
$$

and for the hypothetical hydrolysis reactions in aqueous solution (ionic strength $=0.1$ ) to the ionized species ${ }^{-} \mathrm{OCOC}_{6} \mathrm{H}_{4} \mathrm{~S}^{-}(\mathrm{aq})$

$$
\begin{array}{lll}
+2.20 & \pm 0.15 \mathrm{kcal} / \mathrm{mole} & (o) \\
+1.13 & \pm 0.15 \quad, & (p)
\end{array}
$$

Heats of ionization (ionic strength $=0.1$ ) have been determined for acetic acid, $\Delta H_{\mathrm{i}}=+0.09 \pm 0.05 \mathrm{kcal} / \mathrm{mole}$, and for the protonated form of tris(hydroxymethyl)aminomethane (THAM), $\Delta H_{\mathrm{i}}=+11.36 \pm 0.04 \mathrm{kcal} / \mathrm{mole}$.

* Sponsored by The Swedish Natural Science Research Council and The Swedish Technical Research Council.

Acta Chem. Scand. 18 (1964) No. 4 
This work is part of a systematic study on heats of hydrolysis of i.a. Oand S-esters with special reference to their biochemical importance. Earlier, heats of hydrolysis of simple aliphatic $\mathrm{O}$ - and S-acetates ${ }^{1,2,3}$ as well as of phenylacetate and phenyl thiolacetate ${ }^{4}$ have been investigated.

Thioacyl compounds are reactive intermediates in several enzymatic processes; the most studied are the acylderivatives of coenzyme $A$ and their role in acyl transfer processes. Thioacyl compounds are also believed to be reactive intermediates in the enzymatic hydrolysis of proteins by papain and ficin, see $e . g .{ }^{5,6}$ It has been postulated that the active centers of these enzymes contain a mercaptogroup and a carboxylate ion in close proximity, ${ }^{7-9}$ and so thiosalicylic acid can be regarded as a modelsubstance for them.10 It was therefore felt desirable to determine the heat of hydrolysis of thioaspirin and, as a reference material, of its $p$-isomer. As a comparison, the heats of hydrolysis of the oxygen analogues, aspirin and $p$-acetylhydroxybenzoic acid, have also been determined.

\section{EXPERIMENTAL}

\section{Materials}

Aspirin, pharmaceutical grade, was purified by recrystallization from alcohol-water, ${ }^{11}$ until the equivalent weight, as determined by acidimetric titration after alkaline hydrolysis, was found to be 90.03 Theoretical 90.08 . M.p. $131.2^{\circ}-131.8^{\circ}$.

$p$-Acetylhydroxybenzoic acid was prepared from $p$-hydroxybenzoic acid and acetic anhydride according to the method described for aspirin. ${ }^{11}$ The substance was purified by recrystallization, first from a solution of equal volumes of water and acetic acid, ${ }^{11}$ and then from pure water. The equivalent weight was determined in the same manner as for aspirin and was found to be 90.20. Theoretical 90.08. M.p. $188.7^{\circ}-189.4^{\circ}$.

Thioaspirin was prepared from thiosalicylic acid and acetyl chloride. ${ }^{12}$ The substance was purified by recrystallization from benzene until the equivalent weight as determined by acidimetric titration in water-ethanol was found to be 196.21. Theoretical 196.23. M.p. $125.5^{\circ}-126.0^{\circ}$.

$p$-Acetylmercaptobenzoic acid was prepared from $p$-mercaptobenzoic acid and acetic anhydride ${ }^{13}$ and was purified by recrystallization from a chloroform-benzene solution and then by sublimation. The equivalent weight was determined in the same manner as for thioaspirin and was found to be 196.38. Theoretical 196.23. M.p. $202.8^{\circ}-203.6^{\circ}$.

Salicylic acid, Baker Analyzed Reagent, was purified by recrystallization from water until the equivalent weight as determined by acidimetric titration in water-ethanol was found to be 138.16. Theoretical 138.13. M.p. $157.4^{\circ}-158.0^{\circ}$

$p$-Hydroxybenzoic acid, Kebo purum, was purified by recrystallization from water until the equivalent weight, as determined in the same manner as for salicylic acid, was found to be 138.22. Theoretical 138.13. M.p. $215.8^{\circ}-216.4^{\circ}$.

Thiosalicylic acid exists in two crystalline forms ${ }^{12}$ namely a colourless $\alpha$-form and a yellow $\beta$-form.

$\beta$-Thiosalicylic acid, Fluka puriss p.a., was purified by recrystallization from waterethanol. The equivalent weight as determined by acidimetric titration in water-ethanol was found to be 154.29 , and as determined by iodometric titration in water-ethanol 154.23. Theoretical 154.19. M.p. $166.3^{\circ}-167.3^{\circ}$.

$\alpha$-Thiosalicylic acid was obtained by sublimating $\beta$-thiosalicylic acid in vacuo. The equivalent weight was determined in the same manner as for $\beta$-thiosalicylic acid: by acidimetric titration it was found to be 154.28 , and by iodometric 154.18 Theoretical 154.19. M.p. $166.6^{\circ}-167.2^{\circ}$.

$p$-Mercaptobenzoic acid was prepared from $p$-aminobenzoic acid according to the method described for thiosalicylic acid. ${ }^{14}$ The substance was purified by recrystallization from water-ethanol and by sublimation. The equivalent weight was determined in the 
same manner as for thiosalicylic acid; by acidimetric titration it was found to be 77.44. Theoretical 77.09. By iodometric titration 154.74. Theoretical 154.19. M.p. 221.6 ${ }^{\circ}-$ $-222.4^{\circ}$.

Tris(hydroxymethyl)aminomethane (THAM), "Sigma 7-9", was recrystallized twice from $96 \%$ ethanol and dried at $80^{\circ}$ over night.

\section{Calorimetric measurements}

Apparatus. The measurements were performed with an "isothermal-jacket" glass calorimeter. ${ }^{15}, 16$

Calibration. The heat equivalent of the calorimeter, including its content, was determined electrically by passing a known current for a given time (5-7 mir) through the heating element. The calibrations were performed on the system after reaction had taken place. The initial and final thermistor resistances $\left(R_{\mathrm{i}}\right.$ and $R_{\mathrm{f}}$ respectively) were obtained graphically.

Calorimetric procedure. The calorimeter was charged with $100 \mathrm{ml}$ of liquid: The esters were hydrolyzed in a $0.8 \mathrm{~N}$ sodium hydroxide solution in water-ethanol (2:3). The hydrolysis experiments were supplemented by heats of solution measurements in the hydrolysis medium to arrive at enthalpy data for the standard state. The heats of solution of the two forms of thiosalicylic acid (see under Materials) were measured in $96 \%$ ethanol. The hydrolysis experiments were further supplemented by heats of solution measurements in a solution of THAM in water, ionic strength 0.1 , initial pH 8.05 , and in a $0.1 \mathrm{M}$ solution of sodium chloride in water to give data for the processes in water solution.

When the alkaline mixture of water and ethanol, pure ethanol or aqueous sodium chloride were used as calorimeter media the reactions were very rapid; the reaction period varied between 3 and $7 \mathrm{~min}$ and the initial and final thermistor resistances could be evaluated graphically. No auto-oxidation of the thiols formed was noticed, as was the case with aliphatic thiols. ${ }^{1}$

When the calorimeter liquid was the THAM-solution the reactions were rather slow except for acetic acid and hydrochloric acid. The reaction period varied between 10 and $30 \mathrm{~min}$. Thermal leakages in these cases were calculated by the Regnault-Pfaundler method. ${ }^{17}$ Small corrections were made for differences in stirring energy before and after the ampoules were broken.

Units of measurements. The results of the calorimetric experiments are expressed in terms of the defined calorie, equal to 4.1840 abs. joules and refer to the isothermal process at $25^{\circ} \mathrm{C}$ and to the true mass. The molecular weights were computed from the 1961 table of international atomic weights.

\section{IR measurements}

The infrared stretching frequencies of the acetyl carbonyl groups of aspirin, $p$-acetylhydroxy.benzoic acid, thioaspirin and $p$-acetylmercaptobenzoic acid have been measured in deuterium oxide solution at the Infrared Laboratory, Department of Chemistry, University of Lund. Spectra were obtained with a double-beam Perkin-Elmer model 221 spectrophotometer with sodium chloride prism. A calcium fluoride cell with a pathlength of $0.05 \mathrm{~mm}$ was used.

Solutions were prepared immediately before the spectra were taken. The substance and a stoichiometric amount of sodiumbicarbonate (in order to get the carboxyl group ionized) were dissolved in deuterium oxide. It was, however, impossible to get $p$-acetylmercaptobenzoic acid into solution in this way, owing to its low solubility. This substance was therefore titrated with sodium hydroxide, evaporated to dryness, and then dissolved in deuterium oxide.

The peaks were weak, owing to the low concentration of the substances, less than $0.1 \mathrm{M}$. This was particularly the case for $p$-acetylmercaptobenzoic acid where the uncertainty in the determination of the frequency wos estimated to be $\pm 5 \mathrm{~cm}^{-1}$. 


\section{RESULTS}

1. Heats of hydrolysis for the hypotheticalprocess $\mathrm{RXAc}(\mathrm{s})+\mathrm{H}_{2} \mathrm{O}(\mathrm{l}) \rightarrow \mathrm{RXH}(\mathrm{s})+\mathrm{HOAc}(\mathrm{l})$ at $25^{\circ} \mathrm{C}$ where $\mathrm{R}=(o, p) \mathrm{HOCOC}_{6} \mathrm{H}_{4^{-}}$and $\mathrm{X}=\mathrm{O}$ or $\mathrm{S}$

The esters were hydrolyzed in $0.8 \mathrm{~N}$ sodium hydroxide solution in water ethanol (2:3). In order to get the heats of hydrolysis for the reaction above, heats of solution of the phenols/thiols, acetic acid and water had to be measured in the same liquid.

The results of the calorimetric measurements are summarized in Tables 1 and 2. When five or more determinations were performed, the uncertainties are given as the standard deviation of the mean. Otherwise, they are the average deviation of the mean.

The following symbols have been used:

$\log R_{\mathrm{i}} / R_{\mathrm{f}}=$ the expression proportional to the temperature change; $R_{\mathrm{i}}$ and $R_{\mathrm{f}}$ are the corrected thermistor resistance values at the start and end, respectively, of the main period.

$\varepsilon=$ the heat equivalent of the actual system in calories per unit of $\log R_{\mathrm{i}} / R_{\mathrm{f}}$. $q=$ the amount of heat evolved during the experiment.

Corrections to standard states. The ideal isothermal reaction 5 is obtained from eqns. 1-4, corresponding to the reactions taking place under actual experimental conditions.

1. $\mathrm{RXAc}(\mathrm{s})+\mathrm{H}_{2} \mathrm{O}$ (soln)

2. $\mathrm{RXH}(\mathrm{s})$

$\rightarrow$ RXH(soln) + HOAc(soln)

3. $\mathrm{HOAc}(\mathrm{l})$

$\rightarrow$ RXH(soln)

$\Delta H_{1}$

$\rightarrow \mathrm{HOAc}($ soln $)$

$\Delta H_{2}$

4. $\mathrm{H}_{2} \mathrm{O}(\mathrm{l})$

$\rightarrow \mathrm{H}_{2} \mathrm{O}$ (soln)

$\triangle H_{3}$

5. $\mathrm{RXAc}(\mathrm{s})+\mathrm{H}_{2} \mathrm{O}(\mathrm{l})$ $\Delta H^{\circ}=\Delta H_{1}-\Delta H_{2}-\Delta H_{3}+\Delta H_{4}$

Heats of solution in ethanol of the two forms of thiosalicylic acid were determined. It may be seen from Table 2 that the heat of solution of the $\alpha$ modification is $0.42 \mathrm{kcal} / \mathrm{mole}$ more endotherm than for the $\beta$-modification. This value is equal to the difference in lattice energy. The heat of solution in the alkaline water-ethanol solution of $\alpha$-thiosalicylic acid is thus $-10.85 \mathrm{kcal} / \mathrm{mole}$ $(-11.27+0.42)$. This latter value has been used in the calculations of the standard heat of hydrolysis. Thus $\Delta H^{\circ}$ for thioaspirin refers to the equation

$$
o-\mathrm{HOCOC}_{6} \mathrm{H}_{4} \mathrm{SAc}(\mathrm{s})+\mathrm{H}_{2} \mathrm{O}(\mathrm{I}) \rightarrow(\alpha-) o-\mathrm{HOCOC}_{6} \mathrm{H}_{4} \mathrm{SH}(\mathrm{s})+\mathrm{HOAc}(\mathrm{l})
$$

Table 3 contains a summary of the observed data and the heats of hydrolysis of the idealized reaction 5 . The uncertainties assigned for the $\Delta H^{\circ}$-values include possible systematic errors in the analyses and in the $\varepsilon$-values. All enthalpy values are expressed in $\mathrm{kcal} / \mathrm{mole}$. 
Table 1. Heats of hydrolysis and heats of solution in $0.8 \mathrm{~N}$ sodium hydroxide solution in water-ethanol (2:3).

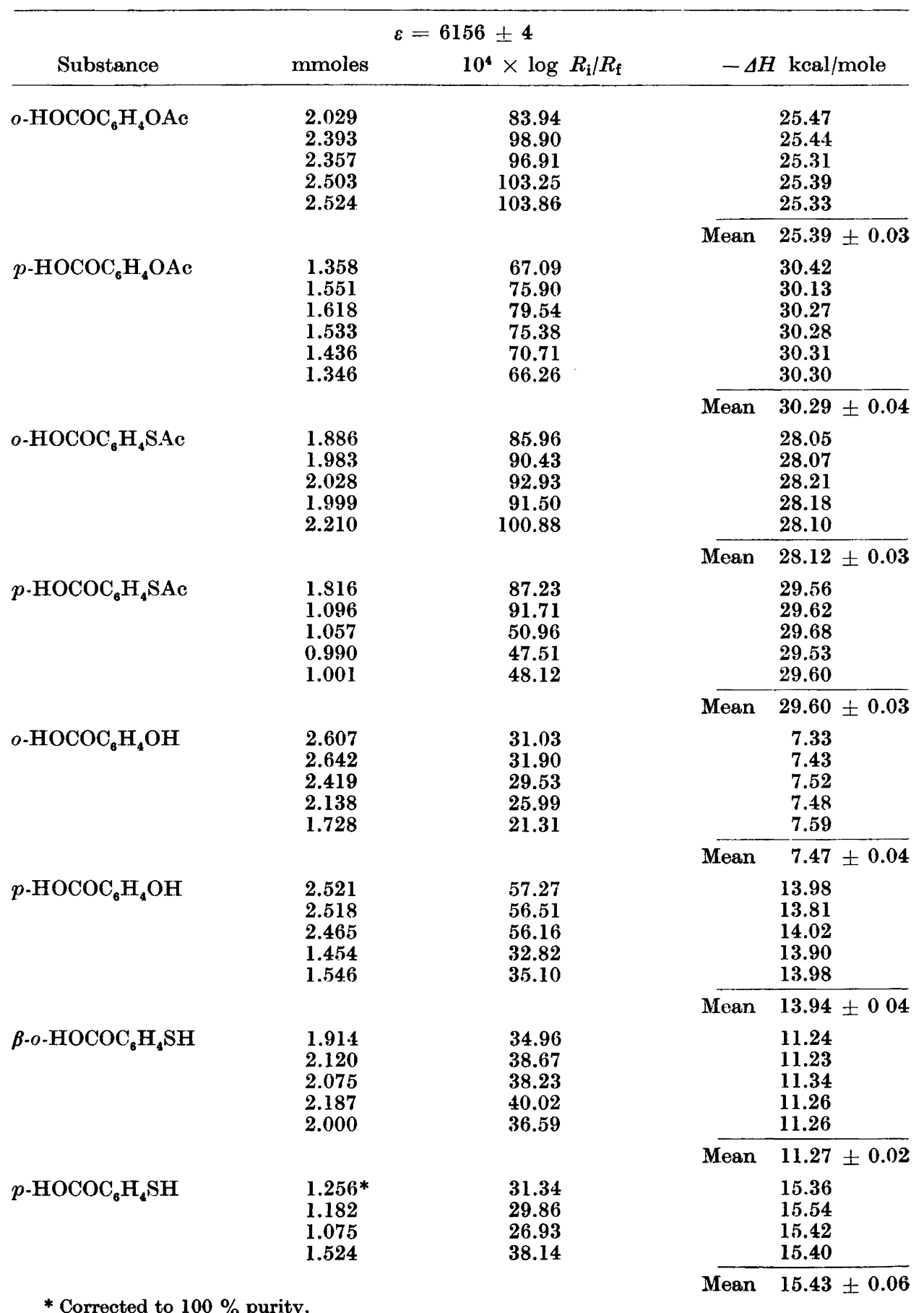


Table 2 Heats of solution in $96 \% \mathrm{EtOH}$.

\begin{tabular}{|c|c|c|c|c|}
\hline \multicolumn{5}{|c|}{$\varepsilon=4159 \pm 5$} \\
\hline Substance & mmoles & $10^{4} \times \log R_{\mathrm{i}} / R_{\mathrm{f}}$ & $\Delta H$ & $\mathrm{kcal} / \mathrm{mole}$ \\
\hline \multirow[t]{2}{*}{$\alpha-0-\mathrm{HOCOC}_{6} \mathrm{H}_{4} \mathrm{SH}$} & $\begin{array}{l}2.071 \\
1.907 \\
1.347 \\
2.006 \\
2.057 \\
2.015\end{array}$ & $\begin{array}{l}-24.14 \\
-22.49 \\
-16.19 \\
-23.73 \\
-24.40 \\
-23.61\end{array}$ & & $\begin{array}{l}4.85 \\
4.91 \\
5.00 \\
4.92 \\
4.93 \\
4.87 \\
\end{array}$ \\
\hline & & & Mean & $4.91 \pm 0.02$ \\
\hline \multirow[t]{2}{*}{$\beta \cdot o-\mathrm{HOCOC}_{6} \mathrm{H}_{4} \mathrm{SH}$} & $\begin{array}{l}1.966 \\
2.078 \\
2.094 \\
1.953 \\
2.224\end{array}$ & $\begin{array}{l}-21.11 \\
-22.50 \\
-22.61 \\
-21.07 \\
-24.20\end{array}$ & & $\begin{array}{l}4.47 \\
4.50 \\
4.49 \\
4.49 \\
4.52\end{array}$ \\
\hline & & & Mean & $4.49 \pm 0.01$ \\
\hline
\end{tabular}

2. Heats of hydrolysis for the hypothetical reactions: $(o, p)^{-} \mathrm{OCOC}_{6} \mathrm{H}_{4} \mathrm{XAc}(\mathrm{aq})+\mathrm{H}_{2} \mathrm{O}(\mathrm{aq})=(o, p)^{-} \mathrm{OCOC}_{6} \mathrm{H}_{4} \mathrm{XH}(\mathrm{aq})+\mathrm{OAc}^{-}(\mathrm{aq})$ $+\mathrm{H}^{+}(\mathrm{aq})$ and

$(o, p)^{-} \mathrm{OCOC}_{6} \mathrm{H}_{4} \mathrm{XAc}(\mathrm{aq})+\mathrm{H}_{2} \mathrm{O}(\mathrm{aq}) \rightarrow(o, p)^{-} \mathrm{OCOC}_{6} \mathrm{H}_{4} \mathrm{X}^{-}(\mathrm{aq})+\mathrm{OAc}^{-}(\mathrm{aq})$ $+2 \mathrm{H}^{+}(\mathrm{aq})$ at $25^{\circ} \mathrm{C}$.

In order to obtain the heats of hydrolysis values for the reactions above, heats of solution in aqueous media had to be measured for all the components listed below in the reaction schemes. As the esters and the corresponding phenols and thiols are only slightly soluble in pure water, a calorimetric liquid had to be chosen where the $\mathrm{pH}$ was sufficiently high to allow the carboxylate groups to be ionized and hence the substances to get into solution, but not so high as to cause hydrolysis of the esters. To fullfil these requirements, a buffer solution had to be used. THAM seemed to be the best choice, as the $\mathrm{p} K$ of its protonated form is 8.07. ${ }^{18}$ The calorimetric measurements are summarized in Tables 4 and 5 .

Table 3. Summary of experimental data and values of heats of hydrolysis of the idealized reaction

$\mathrm{RXAc}(\mathrm{s})+\mathrm{H}_{2} \mathrm{O}(\mathrm{l}) \rightarrow \mathrm{RXH}(\mathrm{s})+\mathrm{HOAc}(\mathrm{l})$

\begin{tabular}{|c|c|c|c|c|c|}
\hline RX. & $-\Delta H_{1}$ & $-\Delta H_{2}$ & $-\Delta H_{3}$ & $-\Delta H_{4}$ & $-\Delta H^{\circ}$ \\
\hline$o-\mathrm{HOCOC}_{6} \mathrm{H}_{4} \mathrm{O}-$ & 25.39 & 7.47 & $11.62^{*}$ & $0.20^{*}$ & $6.50 \pm 0.07$ \\
\hline$p-\mathrm{HOCOC}_{6} \mathrm{H}_{4} \mathrm{O}$ & 30.29 & 13.94 & , &, & $4.93 \pm 0.08$ \\
\hline $0-\mathrm{HOCOC}_{6} \mathrm{H}_{4} \mathrm{~S}$ & 28.12 & 10.85 & ," & ," & $5.85 \pm 0.06$ \\
\hline$p-\mathrm{HOCOC}{ }_{6} \mathrm{H}_{4} \mathrm{~S}$ & 29.60 & 15.43 & ,, &, & $2.75 \pm 0.09$ \\
\hline
\end{tabular}

* Ref. ${ }^{4}$ 
Enthalpy changes for the hydrolysis reactions in aqueous solution eqns. 13 and 14) are derived according to the reaction scheme below:

$$
\varphi=\mathrm{C}_{6} \mathrm{H}_{4} \quad \mathrm{RNH}_{2}=\text { THAM }
$$

5. $(o, p) \mathrm{HOCO} \varphi \mathrm{XAc}(\mathrm{s})+\mathrm{H}_{2} \mathrm{O}(\mathrm{l}) \rightarrow(o, p) \mathrm{HOCO} \varphi \mathrm{XH}(\mathrm{s})+\mathrm{HOAc}(\mathrm{l})$

$\Delta H^{\circ}$

6. $(o, p) \mathrm{HOCO}_{\varphi} \mathrm{XAc}(\mathrm{s})+\mathrm{RNH}_{2}(\mathrm{aq}) \rightarrow(o, p)-\mathrm{OCO} \varphi \mathrm{XAc}(\mathrm{aq})+$ $+\mathrm{RNH}_{3}{ }^{+}(\mathrm{aq})$

7. $(o, p) \mathrm{HOCO} \varphi \mathrm{XH}(\mathrm{s})+(1+\alpha) \mathrm{RNH}_{2}(\mathrm{aq}) \rightarrow \alpha(o, p)-\mathrm{OCO}_{\varphi} \mathrm{X}^{-}(\mathrm{aq})+$ $+(1-\alpha)(o, p)^{-} \mathrm{OCO} \varphi \mathrm{XH}(\mathrm{aq})+(1+\alpha) \mathrm{RNH}_{3}+(\mathrm{aq})$

8. $\mathrm{HOAc}(\mathrm{l})+\mathrm{RNH}_{2}(\mathrm{aq}) \rightarrow \mathrm{OAc}^{-}(\mathrm{aq})+\mathrm{RNH}_{3}+(\mathrm{aq})$

9. $\mathrm{HCl}(\mathrm{l})+\mathrm{RNH}_{2}(\mathrm{aq}) \rightarrow \mathrm{RNH}_{3}^{+}(\mathrm{aq}) \mathrm{Cl}^{-}(\mathrm{aq})$

10. $\mathrm{HCl}(\mathrm{l})$

$\rightarrow \mathrm{H}^{+}(\mathrm{aq}) \mathrm{Cl}^{-}(\mathrm{aq})$

11. $(o, p)^{-} \mathrm{OCO} \varphi \mathrm{XH}(\mathrm{aq}) \rightarrow{ }^{-} \mathrm{OCO} \varphi(\mathrm{aq})+\mathrm{H}^{+}(\mathrm{aq})$

$\Delta H_{7}$

12. $\mathrm{H}_{2} \mathrm{O}(\mathrm{l})$

$\rightarrow \mathrm{H}_{2} \mathrm{O}(\mathrm{aq})$

$\Delta H_{8}$

$\Delta H_{9}$

$\Delta H_{10}$

$\Delta H_{11}$

$\Delta H_{12}$

13. $(o, p)^{-} \mathrm{OCO} \varphi \mathrm{XAc}(\mathrm{aq})+\mathrm{H}_{2} \mathrm{O}(\mathrm{aq}) \rightarrow(o, p)^{-} \mathrm{OCO} \varphi \mathrm{XH}(\mathrm{aq})+$ $+\mathrm{OAc}^{-}(\mathrm{aq})+\mathrm{H}^{+}(\mathrm{aq})$

$\Delta H_{(\mathrm{aq}) 13}=\Delta H^{\circ}-\Delta H_{6}+\Delta H_{7}+\Delta H_{8}-(1+\alpha) \Delta H_{9}+$

$+(1+\alpha) \Delta H_{10}-\alpha \Delta H_{11}-\Delta H_{12}$

14. $(o, p)^{-} \mathrm{OCO} \varphi \mathrm{XAc}(\mathrm{aq})+\mathrm{H}_{2} \mathrm{O}(\mathrm{aq}) \rightarrow(o, p)^{-} \mathrm{OCO} \varphi \mathrm{X}^{-}(\mathrm{aq})+$

$+\mathrm{OAc}^{-}(\mathrm{aq})+2 \mathrm{H}^{+}(\mathrm{aq})$

$\Delta H_{(\mathrm{aq}) 14}=\Delta H^{\circ}-\Delta H_{6}+\Delta H_{7}+\Delta H_{8}-(1+\alpha) \Delta H_{9}+$

$+(1+\alpha) \Delta H_{10}+(1-\alpha) \Delta H_{11}-\Delta H_{12}$

In Table 6 are summarized data for reactions $5-14 . \Delta H_{11}$ is $+8.51 \pm 0.08$ $\mathrm{kcal} / \mathrm{mole}$ for salicylic acid ${ }^{28}$

$+3.4 \pm 1 \mathrm{kcal} / \mathrm{mole}$ for $p$-hydroxybenzoic acid 19

$+5.72 \pm 0.08 \mathrm{kcal} /$ mole for thiosalicylic acid ${ }^{20}$

$\Delta H_{11}$ could not be measured calorimetrically for $p$-mercaptobenzoic acid ${ }^{20}$ but was believed to be very low, around zero. It is therefore not possible to give a reliable value for the heat of hydrolysis for $p$-acetylmercaptobenzoic acid referring to eqn. 13, but it is estimated bo be around zero. As, however, $p$-mercaptobenzoic acid is almost completely ionized in the calorimetric measurement (the degree of ionization of $p{ }^{-} \mathrm{OCOC}_{6} \mathrm{H}_{4} \mathrm{SH}$ is 0.996 ) it is possible to calculate the heat of hydrolysis referring to eqn. 14 .

$\Delta H_{12}$ is taken equal to zero. ${ }^{21}$ The uncertainties assigned for the $\Delta H_{\mathrm{aq}^{-}}$ values include possible systematic errors in the analyses and in the $\varepsilon$-values. All enthalpy values are expressed in $\mathrm{kcal} / \mathrm{mole}$.

\section{Heats of ionization.}

From the heats of solution of aqueous hydrochloric acid, $1.690 \mathrm{mmole} /$ $\mathrm{g}$ in the aqueous THAM solution $(\Delta H=-11.89 \pm 0.04 \mathrm{kcal} / \mathrm{mole})$ and in $0.1 \mathrm{M}$ sodium chloride $(\Delta H=-0.53 \pm 0.01 \mathrm{kcal} / \mathrm{mole})$ the heat of ionization of the protonated form of THAM is calculated to be $+11.36 \pm 0.04 \mathrm{kcal} /$ mole (ionic strength 0.1 ) This value should be compared with the value obtained calorimetrically at ionic strength $0.013,+10.93 \pm 0.10 \mathrm{kcal} / \mathrm{mole}^{22}$

Acta Chem. Scand. 18 (1964) No. 4 
Table 4. Heats of solution in the aqueous THAM solution, ionic strength 0.1 Initial pH 8.05

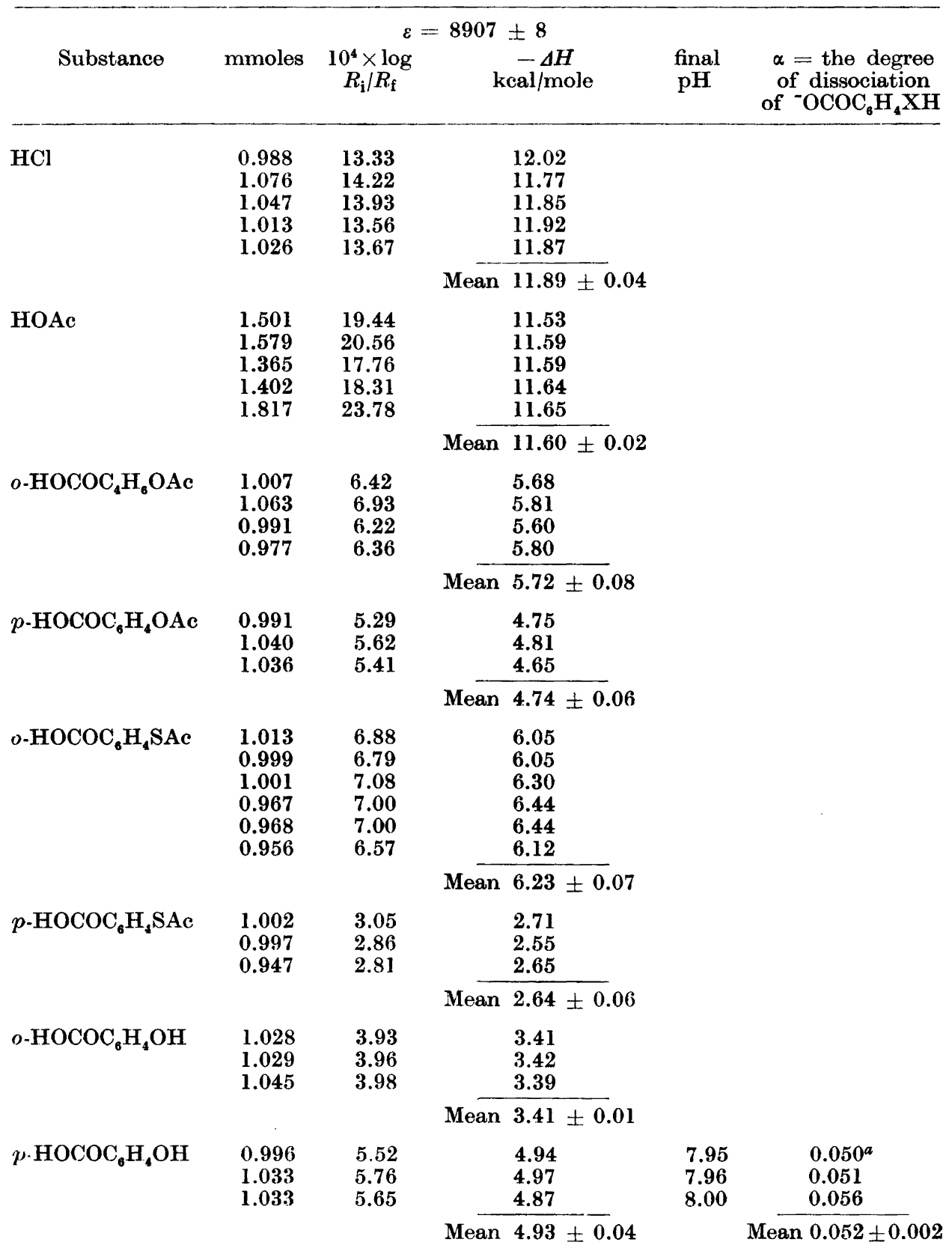


Table 4, continued.

\begin{tabular}{cccccc}
$\alpha-o-\mathrm{HOCOC}_{6} \mathrm{H}_{4} \mathrm{SH}$ & $\mathbf{0 . 9 4 1}$ & $\mathbf{4 . 8 4}$ & 4.58 & 7.88 & $0.187^{b}$ \\
& 0.944 & 4.93 & 4.65 & 7.86 & 0.180 \\
& 0.999 & 5.40 & 4.81 & 7.85 & 0.177 \\
& 0.861 & 4.53 & 4.69 & 7.88 & 0.187 \\
\hline & & Mean $4.68 \pm 0.07$ & & Mean $0.182 \pm 0.004$ \\
$p-\mathrm{HOCOC}_{6} \mathrm{H}_{4} \mathrm{SH}$ & 0.984 & 10.76 & 9.73 & 7.86 & $0.996^{c}$ \\
& 0.963 & 10.62 & 9.82 & 7.85 & 0.996 \\
& 1.063 & 11.85 & 9.93 & 7.83 & 0.996 \\
\hline & & & Mean $9.83 \pm 0.07$ & & Mean $0.996 \pm 0$
\end{tabular}

${ }^{a} \mathrm{p} K_{2}{ }^{\prime}$ (ionic strength 0.1$)=9.11 .^{19}$

${ }^{b} \mathrm{p} K_{2}=8.88,{ }^{20} \mathrm{pK}_{2}^{\prime}$ (ionic strength 0.1) calculated to be 8.40.

${ }^{c} \mathrm{pK}_{2}=5.80,{ }^{20} \mathrm{pK}_{2}^{\prime}$ (ionic strength 0.1 ) calculated to be 5.32 .

Table 5. Heat of solution for aqueous hydrochloric acid, $1.690 \mathrm{mmoles} / \mathrm{g}$ in aqueous sodium chloride, ionic strength 0,1

\begin{tabular}{ccc}
\hline & \multicolumn{1}{c}{$\varepsilon=8907 \pm 8$} & \\
mmoles & $10^{4} \times \log R_{\mathrm{i}} / R_{\mathrm{f}}$ & $-\Delta H$ kcal $/$ mole \\
\hline 1.045 & 0.613 & 0.523 \\
0.943 & 0.559 & 0.528 \\
1.101 & 0.649 & $\frac{0.525}{0.525 \pm 0.002}$
\end{tabular}

and the values obtained at zero ionic strength by measuring the dissociation constant at various temperatures; $+11.38 \mathrm{kcal} / \mathrm{mole}^{18}$ and $+11.33 \mathrm{kcal} /$ mole. ${ }^{23}$

From the heats of solution of acetic acid in the aqueous THAM solution $(\Delta H=-11.60 \pm 0.02 \mathrm{kcal} / \mathrm{mole})$ and in a solution where no ionization occurs $(\Delta H=-0.33 \pm 0.01 \mathrm{kcal} / \mathrm{mole})^{16}$ and from the value of the heat of ionization of the protonated form of THAM above, the heat of ionization of acetic acid is calculated to be $+0.09 \pm 0.05 \mathrm{kcal} / \mathrm{mole}$ (ionic strength 0.1). This value is in reasonable agreement with other recent calorimetric measurements; $-0.07 \pm 0.05 \mathrm{kcal} /$ mole at zero ionic strength ${ }^{24}$ and +0.18 $\pm 0.05 \mathrm{kcal} / \mathrm{mole}$ at ionic strength $0.2 .{ }^{16}$

Table 6. Summary of experimental data and values of heats of hydrolysis in aqueous solution.

\begin{tabular}{|c|c|c|c|c|c|c|c|c|c|c|}
\hline \multirow{2}{*}{$\begin{array}{l}\text { jub- } \\
\text { ance }\end{array}$} & \multirow[b]{2}{*}{$\Delta H^{\circ}$} & \multirow[b]{2}{*}{$\Delta H_{6}$} & \multirow[b]{2}{*}{$\Delta H_{7}$} & \multirow[b]{2}{*}{$\Delta H_{8}$} & \multicolumn{2}{|c|}{$\mathrm{R}={ }^{-} \mathrm{OCOC}_{6} \mathrm{H}_{4}$} & \multirow[b]{2}{*}{$\Delta H_{11}$} & \multirow[b]{2}{*}{$\alpha$} & \multirow[b]{2}{*}{$\Delta H_{\mathrm{aq}, 13}$} & \multirow[b]{2}{*}{$\Delta H_{\mathrm{aq}_{14}}$} \\
\hline & & & & & $\Delta H_{9}$ & $\Delta H_{10}$ & & & & \\
\hline $\begin{array}{l}\text { iOAc } \\
\text { iOAc } \\
\text { iSAc } \\
\text { iSAc }\end{array}$ & $\begin{array}{l}-6.50 \\
-4.93 \\
-5.85 \\
-2.75\end{array}$ & $\begin{array}{l}-5.72 \\
-4.74 \\
-6.23 \\
-2.64\end{array}$ & $\begin{array}{l}-3.41 \\
-4.93 \\
-4.68 \\
-9.83\end{array}$ & $\begin{array}{l}-11.60 \\
-11.60 \\
-11.60 \\
-11.60\end{array}$ & $\begin{array}{l}-11.89 \\
-11.89 \\
-11.89 \\
-11.89\end{array}$ & $\begin{array}{l}-0.53 \\
-0.53 \\
-0.53 \\
-0.53\end{array}$ & $\begin{array}{l}+8.51 \\
+3.4 \\
+5.72 \\
\text { ca. } 0\end{array}$ & $\begin{array}{l}0 \\
0.052 \\
0.182 \\
0.996\end{array}$ & $\begin{array}{l}-4.43 \pm 0.12 \\
-4.95 \pm 0.16 \\
-3.52 \pm 0.15 \\
(0)\end{array}$ & $\begin{array}{l}+4.08 \pm 0.14 \\
-1.6 \pm 1 \\
+2.20 \pm 0.15 \\
+1.13 \pm 0.15\end{array}$ \\
\hline
\end{tabular}

Acta Chem. Scand. 18 (1964) No. 4 
Table 7. IR carbonyl frequencies in deuterium oxide.

\begin{tabular}{cc}
\hline Substance & IR carbonyl frequency, $\mathrm{cm}^{-1}$ \\
\hline$o-{ }^{-} \mathrm{OCOC}_{6} \mathrm{H}_{4} \mathrm{OAc}$ & 1730 \\
$p-\mathrm{OCOC}_{6} \mathrm{H}_{4} \mathrm{OAc}$ & 1730 \\
$o-{ }^{-} \mathrm{OCOC}_{6} \mathrm{H}_{4} \mathrm{SAc}$ & 1675 \\
$p-\mathrm{OCOC}_{6} \mathrm{H}_{4}^{4} \mathrm{SAc}$ & 1675
\end{tabular}

\section{I R m e s u rements.}

In Table 7 are given the infrared stretching frequencies of the acetyl carbonyl groups of aspirin, $p$-acetylhydroxybenzoic acid, thioaspirin and $p$-acetylmercaptobenzoic acid.

\section{DISCUSSION}

In order to enable a close comparison between different thermochemical data, it is necessary that they refer to comparable aggregation states, preferably the ideal gaseous state where there are no intermolecular interactions. For most of the compounds involved in this study, however, no vaporization data are as yet available. The thermochemical standard state data (eqn. 5) are not internally comparable as lattice energies can be expected to be considerably different for the corresponding reaction components. Nevertheless the $\Delta H^{\circ}$ values are in a general agreement with those for the unsubstituted phenylacetate and phenyl thiolacetate, -6.86 and $-2.97 \mathrm{kcal} / \mathrm{mole}$, respectively. ${ }^{4}$

The results for the hydrolyses in aqueous solution (eqns. 13 and 14) are somewhat more favourable for a comparison. The enthalpy values for the hydrolysis reactions as carried out in aqueous solution can formally be looked upon as being composed of two effects: (1) breaking and formation of chemical bonds, and electronic and steric rearrangements, (2) solvation enthalpies. For the two $\mathrm{O}$ - and S-esters, respectively, there is no difference in chemical bond rearrangements. The ester carbonyl stretching frequencies in $\mathrm{D}_{2} \mathrm{O}$ are equal for the two $O$-esters and at least very similar for the two S-esters. It thus seems that the resonance stabilization of the two isomeric forms of the $\mathrm{O}$ - and S-ester, respectively, are the same. ${ }^{25}$

Salicylic acid is a considerably stronger acid than its $p$-isomer $\left(K_{1, o} / K_{1, p}\right.$ ca. 30) see, e.g. Ref. ${ }^{26}$ This has been explained by Branch and Yabroff ${ }^{26}$ as caused by an internal hydrogen bond formation in salicylic acid. The hydrogen bond should stabilize the $o$-hydroxybenzoate ion and thus the $\Delta H_{\text {aq }}$ value (the hydroxy group unionized) should be more exothermic for aspirin than for $p$-acetylhydroxybenzoic acid. This is in contrast to the experimental results obtained here, where $\Delta H_{\mathrm{aq}}$ is found to be about $0.5 \mathrm{kcal} / \mathrm{mole}$ more exothermic for the $p$-isomer. This difference is suggested to be caused by differences in solvation enthalpies.

Scheraga et al. ${ }^{19}$ calculated the heat of isomerization of the $p$ - to the $o$-hydroxybenzoate ions to be $-5.0 \mathrm{kcal} / \mathrm{mole}$. They called this value the heat of 
formation of the hydrogen bond in the o-hydroxybenzoate ion, but as it includes the difference of solvation enthalpies between the two isomeric ions, heat of isomerization seems to be a more adequate name. Using the value of Scheraga et al. and the values for the heats of hydrolysis in aqueous solution obtained here (the hydroxy groups unionized), the heat of isomerization for the $p$ - and $o$-acetylhydroxybenzoate ions is calculated to be -5 to $-6 \mathrm{kcal} / \mathrm{mole}$.

A strong internal hydrogen bond is not expected for thiosalicylic acid, as work on hydrogen bonding of benzenethiol with serveral hydrogen acceptors ${ }^{27}$ showed that the benzenethiol hydrogen bonding interaction is weak relative to its oxygen analogue. But if a sufficiently strong intramolecular hydrogen bond exists one would expect the $\Delta H_{\text {aq }}$ value (the mercapto groups unionized) for thioaspirin to be more exothermic than for $p$-acetylmercaptobenzoic acid, as was expected for the hydroxy esters. As the $\Delta H_{\text {aq-value }}$ (the mercapto group unionized) for $p$-acetylmercaptobenzoic acid is very uncertain (see under Results) nothing can be discussed in this case.

In the completely ionized thiosalicylic acid, however, no hydrogen bond exists and therefore the less endothermic $\Delta H_{\text {aq }}$-value (the mercapto groups ionized) for $p$-acetylmercaptobenzoic acid compared with its $o$-isomer is believed to be caused by differences in solvation enthalpies.

Schonbaum and Bender 10 investigated the catalytic properties showed by thiosalicylic acid on the hydrolysis of $p$-nitrophenylacetate. Their experiments indicated that the catalytic properties were caused by the close orientation of the mercapto and carboxylate groups and it was shown that the S-acetate (thioaspirin) was formed as an intermediate. Smith ${ }^{7}$ originally proposed a two-step process for papain catalysis with the formation of a thiol ester as an intermediate. This hypothesis has later been critized by him ${ }^{6}$ as being unlikely as the free energy of transacylation substrate $\rightarrow$ mercapto group should be a highly endergonic reaction step. Work on the hydrolysis of $\mathrm{O}$ and S-esters ${ }^{3}$ showed that for comparable compounds there is only a small

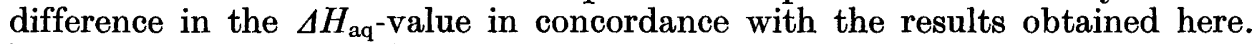
It is therefore not believed that thermodynamic arguments, at present, discard the tiolester-intermediate hypothesis as changes in the entropy term easily might compensate the minor unfavourable enthalpy change.

Acknowledgements. I want to express my sincere thanks to Dr. I. Wadsö for valuable discussions. This work has been supported by grants from the University of Lund.

\section{REFERENCES}

1. Wadsö, I. Acta Chem. Scand. 11 (1957) 1745.

2. Wadsö, I. Acta Chem. Scand. 12 (1958) 630.

3. Wadsö, I. Acta Chem. Scand. 16 (1962) 487.

4. Wadsö, I. Acta Chem. Scand. 14 (1960) 561.

5. Gutfreund, H. Discussions Faraday Soc. 20 (1955) 167.

6. Smith, E. L. J. Biol. Chem. 233 (1958) 1392.

7. Stockell, A, and Smith, E. L. J. Biol. Chem. 227 (1957) 1.

8. Bernhard, S. A. and Gutfreund, H. Biochem. J. 63 (1956) 61.

9. Hammond, B. R. and Gutfreund, H. Biochem. J. 72 (1959) 349.

10. Schonbaum, G. R. and Bender, M. L. J. Am. Chem. Soc. 82 (1960) 1900.

Acta Chem. Scand. 18 (1964) No. 4 
11. Vogel, A. I. A Textbook of Practical Organic Chemistry. 3rd Ed., Longmans. Green and Co., London, p. 996.

12. Hinsberg, O. Chem. Ber. 43 (1910) 651.

13. Bordwell, F. G. and Boutan, P. J. J. Am. Chem. Soc. 78 (1956) 854.

14. Allen, C. F. H. and MacKay, D. D. in Blatt, A. H. Org. Syn. Coll. Vol. II, p. 580.

15. Sunner, S. and Wadsö, I. Acta Chem. Scand. 13 (1959) 97.

16. Wadsö, I. Acta Chem. Scand. 16 (1962) 479.

17. See e.g. Sturtevant, J. M. in Weissberger, A. (Ed.) Physical Methods of Organic Chemistry, 2nd Ed., Part I, Interscience Publ., New York 1949.

18. Bates, R. G. and Hetzer, H.B. J. Phys. Chem. 65 (1961) 667.

19. Hermans, J., Jr., Leach. S. J. and Scheraga, H. A. J. Am. Chem. Soc. 85 (1963) 1390.

20. Irving, R. J. Nelander, L. and Wadsö, I. Acta Chem. Scand. 18 (1964) 769.

21. Rossini, F. D., Wagman, D. D., Evans, W. H., Levine, S. and Jaffe, I. Selected Values of Chemical Thermodynamic Properties, Circular of the National Bureau of Standards 500, US Government Printing Office, Washington 1952.

22. Sturtevant. J. M. J. Am. Chem. Soc. 77 (1955) 1495.

23. Datta, S. P., Grzynbowski, A. K. and Weston, B. A. J. Chem. Soc. 1963792.

24. Canady, W. J., Papée, H. M. and Laidler, K. J. Trans. Faraday Soc. 54 (1958) 502.

25. Jencks, W. P., Moore, C., Perini, F. and Roberts, J. Arch. Biochem. Biophys. 88 (1960) 193.

26. Branch, G. E. K. and Yabroff, D. L. J. Am Chem. Soc. 56 (1934) 2568.

27. Mathur, R., Becker, E. D., Bradley, R. B. and Li N. C. J. Phys. Chem. 67 (1963) 2190.

28. Ernst, Z. L., Irving, R. J. and Menashi, J. Trans. Faraday Soc. 60 (1964) 56.

Received January 24, 1964. 